\title{
SISTEM PENDUKUNG KEPUTUSAN PEMILIHAN PEKERJAAN MENGGUNAKAN METODE FUZZY MAMDANI STUDI KASUS: AMIK BSI TASIKMALAYA
}

\author{
Herlan Sutisna ${ }^{1}$, dan Noor Cholis Basjaruddin ${ }^{2}$ \\ ${ }_{1,2}$ AMIK BSI Tasikmalaya \\ ${ }^{1}$ herlan.her@bsi.ac.id, ${ }^{2}$ cs_ppm@yahoo.com
}

\begin{abstract}
The Policy in taking a decision on a particular issue is not an easy thing, because it needs to be a consideration that is expected to help justify certain decisions must be taken. Likewise, the handling of the problem of determining employment options for someone to work according to their talents and interests. Someone who will be joining or working in a company the necessary things that need to be considered are of such quality and age, GPA quality and desired salary of the person. Job Selection Decision Support System is the most appropriate for handling problems that require independent completion of a computer for someone who input the data processing data with efficient and accurate calculations. By using Mamdani Fuzzy Logic reasoning in the processing of data input and output, as well as supporting information in the form of Recommendation job what is right for the person.
\end{abstract}

Keywords : Decision Support System, Job Selection, Fuzzy Logic

\begin{abstract}
Abstraksi - Kebijaksanaan dalam mengambil sebuah keputusan pada permasalahan tertentu bukan lah hal yang mudah, karena perlu dilakukan pertimbangan yang diharapkan dapat membantu memberikan alasan keputusan tertentu tersebut harus diambil. Begitu juga penanganan masalah dalam penentuan pilihan pekerjaan bagi seseorang. Pemilihan jenis pekerjaan seharusnya disesuaikan dengan kemampuan dan minat yang dimiliki seseorang. Seseorang yang akan bekerja pada sebuah perusahaan mempertimbangkan umur, IPK, dan gaji yang diinginkan.Sistem Pendukung Keputusan Pemilihan Pekerjaan yang dikembangkan diharapkan dapat membantu calon pekerja dalam menentukan pilihannya. Penalaran Logika Fuzzy Mamdani digunakan untuk memproses data masukan yang selanjutnya digunakan untuk menghasilkan keluaran berupa rekomendasi pekerjaan apa yang tepat bagi seseorang
\end{abstract}

Kata kunci: Sistem Pendukung Keputusan, Pemilihan Pekerjaan, Logika Fuzzy, Mamdani

\section{PENDAHULUAN}

Dengan berkembangnya teknologi informasi secara tidak langsung juga mempengaruhi kualitas dari informasi yang diberikan. Perkembangan ilmu pengetahuan dan teknologi memicu banyak kalangan untuk mencari alternatif pemecahan masalah di bidang teknologi sistem informasi.Penggunaan aplikasi perangkat lunak sebagai alat bantu penyelesaian pekerjaan kian marak dan berkembang di segala bidang dan juga dapat disesuaikan dengan keinginan pemakainya.
Dalam teorinya David V. Tiedeman (Sukardi, 1987:89) mengemukakan bahwa keputusan untuk pemilihan pekerjaan, jabatan atau karir tertentu merupakan suatu rentetan akibat dari keutusan keputusan yang dibuat individu pada tahap-tahap kehidupannya di masa lalu. pembuatan keputusan menurut David V. Tiedeman dibagi menjadi dua periode, yaitu periode antisipasi (anticipation) dan implementasi (implementation). kedua periode ini merupakan inti dari suatu perkembangan kariri. perkembangan pekerjaan itu diorientasikan dari keputusan mengenai sekolah, kerja dan kehidupannya. 
1). Periode Antisipasi (The Period of Anticipation)

Tiedeman dan o"Hara (sharf, 1992:307) membagi antisipasi dalam membuat keputusan karir menjadi empat proses, yaitu eksplorasi, kristalisasi, pemilihan dan klarifikasi. miller dan Tiedeman (1989) menegaskan bahwa tahapan tersebut sebagai panduan (guideline) dalam mengantisipasi suatu keputusan.

a)ekspolari

Ekspolarasi yang dimaksud adalah penjelajahan terhadap kemungkinan alternatif keputusan yang akan diambil. melalui eksplorai ini, individu mengetahui dengan jelas konsekuensi apa yang akan dialami jika mengambil keutusan tersebut.

b). Kristalisasi

Tiedeman dan O"Hara (Sharf, 1992:308) nerasumsi bahwa kristalisasi merupakan stabilisasi dari refresentasi berpikir.pada tahap ini, pemikiran dan perasaan mulai teradu dan teratur. keyakinan atas pemilihan yang akan diambil menguat. definisi tentang alternatif pilihan semakin jelas.

\section{c). Pemilihan}

sama halnya dengan perkembangan kristalisasi, proses pemilihan pu terjadi. masalah-masalaj individu berorientasi kepada tujuan yang relevan, yaitu individu mulai mengorganisir dalam melengkapi dan menyesuaikan terhadap berbagai pilihan karir masa depan. Sehingga pada tahap ini individu percaya atas pilihannya.

\section{d). Klarifikasi}

ketika seorang individu membuat keputusan lalu melakukannya. Mungkindalam perjalanannya ada yang lancar mungkin ada yang mempertanyakan seharusnya individu tersebut melakukan eksplorasi kembali, kristalisasi, lalu melakukan pemilihan alternatif kembali dan seterusnya.

2. Periode Implementasi dan penyesuaian (The Period of Implementation and Adjustment)
Periode implementasi dan penyesuaian ini oleh David V. Tiedeman digolongkan menjadi tiga tahap, yaitu: tahap induksi (induction), tahap transisi (Transtition), dan tahap mempertahankan (maintenance).

a). Tahap Induksi.

periode ini terjadi atau dimulai dari pengalaman dan kesimpulan yang diteliti. individu mengorganisir karir dari tujuan individu kedalam interaksi yang berhubungan dengan masyarakat (misal melanjutkan sekolah atau pekerjaan). selama tahap ini, individu mengutamakan hal-hal yang berkaitan dengan tujuan yang telah dicapainya. akhirnya pada tahap ini tujuan dan sejumlah alternatif menjadi suatu bagian. Dalam arti lain, tujuan individi dan dunia kerja berasimilasi dengan posisinya sebagai salah satu aspek yang memungkinkan mendorongnya untuk berhasil.

b). Tahap Transisi

Dalam tahap ini, orientasi yang diutamakan adalah disesuaikan kepada penetapan tujuan karir yang diambilnya. Walaupun telah diperoleh kepercayaan bahwa seseorang akan berhasil terhadap pembuatan keputusan karirnya, akan tetapi seorang individu masih mengalami tahap transisi berbagai keputusan yang telah diambilnya, yaitu adanya berbagai kemungkinan bahwa individu akan menyimpang arah.

c). Tahap Mempertahankan

pada tahap mempertahankan, individu memelihara keputusan karir yang telah diambilnya. Prospek terhadap segala usahanya telah menuju kepada status dimasa mendatang dan seterusnya akan berkembang menjadi pembinaan karir.

Pemilihan pekerjaan bagi mahasiswa pada sebuah perusahaan, instansi pemerintah atau swasta, merupakan sebuah persoalan yang membutuhkan penanganan yang baik. Pemilihan pekerjaan adalah persoalan yang komplek karena beberapa hal berikut:

1. Tingkat pengangguran yang tinggi sehingga persaingan untuk mendapatkan pekerjaan semakin ketat. 
2. Lowongan atau peluang kerja, baik di sebuah lembaga swasta maupun lembaga negeri yang relatif terbatas.

3. Tuntutan hidup yang semakin berat dan meningkat.

4. Keterbatasan wawasan mahasiswa tentang dunia kerja sehingga peminatan dan kemampuan kerap tidak sesuai.

Memilih dan merencanakan karir merupakan salah satu tugas perkembangan pada masa remaja. Hakikat perkembangan ini adalah memilih suatu pekerjaan yang sesuai dengan kemampuannya dan mempersiapkan diri memiliki pengetahuan dan keterampilan untuk memasuki pekerjaan tersebut. Dasar psikologis studi tentang minat remaja, menunjukkan bahwa perencanaan dan persiapan pekerjaan merupakan minatnya yang pokok, baik remaja pria maupun wanita.

Sistem pendukung keputusan pemilihan pekerjaan dapat membantu mahasiswa yang ingin memilih pekerjaan yang tepat sesuai dengan kemampuannya, sehingga bisa mempersiapkan diri untuk pekerjaan yang diinginkan atau yang disarankan oleh sistem.

\section{KAJIAN LITERATUR}

\subsection{Sistem}

Sistem adalah sekumpulan objek, ide, yang saling berhubungan dalam mencapai tujuan atau sasaran bersama (Turban, 2000)

\subsection{Informasi}

Informasi adalah rangkaian data yang mempunyai sifat sementara, tergantung dengan waktu, mampu memberi kejutan pada yang menerimanya. Intensitas dan lamanya kejutan dari informasi disebut nilai informasi. Informasi yang tidak mempunyai nilai, biasanya karena rangkaian data yang tidak lengkap atau kadaluarsa. (Jogianto, 2003)

\subsection{Sistem Pendukung Keputusan (Decision Support System)}

Keputusan adalah suatu pengakhiran daripada proses pemikiran tentang suatu masalah atau problema untuk menjawab pertanyaan apa yang harus diperbuat guna mengatasi masalah tersebut, dengan menjatuhkan pilihan pada suatu alternatif (Hasan, 2002).Pada dasarnya pengambilan keputusan merupakan suatu bentuk pemilihan dari berbagai alternatif tindakan yang mungkin dipilih, yang prosesnya melalui mekanisme tertentu, dengan harapan akan menghasilkan sebuah keputusan yang terbaik.

Penyusunan sebuah model keputusan merupakan suatu cara untuk mengembangkan hubungan-hubungan logis yang mendasari persoalan keputusan ke dalam suatu bentuk model matematis, yang mencerminkan hubungan di antara faktor faktor yang terlibat. Model yang menggambarkan proses pengambilan keputusan terdiri dari empat fase yaitu:

1. Penelusuran (Intelligence)

$\begin{array}{lrr}\text { Tahap ini merupakan tahap } \\ \text { pendefinisian masalah } & \text { serta } \\ \text { identifikasi informasi yang } \\ \text { dibutuhkan yang berkaitan } & \text { dengan } \\ \text { persoalan yang dihadapi } & \text { serta } \\ \text { keputusan yang akan diambil. } & \end{array}$

2. Perancangan (Design)

Tahap ini merupakan suatu proses untuk merepresentasikan model sistem yang akan dibangun berdasarkan pada asumsi yang telah ditetapkan. Dalam tahap ini, suatu model dari masalah dibuat, diuji, dan divalidasi.

3. Pemilihan (Choice)

Tahap ini merupakan suatu proses melakukan pengujian dan memilih keputusan terbaik berdasarkan kriteria tertentu yang telah ditentukan dan mengarah kepada tujuan yang akan dicapai.

4. Implementasi (Implementation)

Tahap ini merupakan tahap pelaksanaan dari keputusan yang telah diambil. Pada tahap ini perlu disusun serangkaian tindakan yang terencana, sehingga hasil keputusan dapat dipantau dan disesuaikan apabila diperlukan perbaikan perbaikan.

\subsection{Logika Fuzzy}

Logika Fuzzy (Fuzzy Logic) merupakan cabang dari sistem kecerdasan buatan (artificial intelegent) yang memungkinkan kemampuan manusia 
dalam berfikir dibuat dalam bentuk algoritma yang kemudian dijalankan oleh mesin (komputer). Algoritma ini digunakan dalam berbagai aplikasi pemrosesan data yang tidak dapat direpresentasikan dalam bentuk biner. Fuzzy Logic menginterpretasikan statemen yang samar menjadi sebuah pengertian yang logis.

Fuzzy dipresentasikan bukan sebagai metodologi kontrol, namun sebagai suatu cara pemrosesan data yang memperbolehkan anggota himpunan parsial daripada anggota himpunan kosong atau non-anggota. Pendekatan ini pada teori himpunan tidak diaplikasikan untuk mengontrol sistem sampai tahuan 70-an karena kurangnya kemampuan komputermini pada saai itu (Kusrini, 2008). Pelopor aplikasi Fuzzi Set dalam bidang kontrol yang merupakan aplikasi pertama dan utama dari Fuzzy Set adalah Prof. Ebrahim Mamdani dan kawan-kawan dari Queen Mary College London. Penerapan Fuzzy secara nyata di industri banyak dipelopori para ahli dari Jepang, misalnya Prof. Sugeno dari Tokyo Institute of Technology, Prof.Yamakawa dari Kyusu Institute of Technology, Togay dan Watanabe dari Bell Telephone Labs.

Metode logika fuzzy memiliki tiga tahapan proses fuzzifikasi, inferensi dan defuzzifikasi. Logika fuzzy adalah nilai yang memiliki samar (fuzzyness) antara benar dan salah. Secara teori, logika fuzzy bisa bernilai benar dan salah pada saat yang sama tapi berapa banyak kebenaran dan kesalahan suatu nilai tergantung pada berapa banyak berat badan keanggotaannya. Secara teori, logika fuzzy, himpunan fuzzy dikenal (fuzzy set) yang merupakan pengelompokan sesuatu berdasarkan variabel bahasa (variabel linguistik) yang dinyatakan dalam nilai fungsi keanggotaan dari nol sampai satu.. Pengontrol dengan Fuzzy Logic mempunyai kelebihan yaitu dapat mengontrol sistem yang kompleks, nonlinier, atau sistem yang sulit direpresentasikan kedalam bentuk matematis. Selain itu, informasi berupa pengetahuan dan pengalaman mempunyai peranan penting dalam mengenali perilaku sistem di dunia nyata. Fuzzy Logic juga memiliki himpunan Fuzzy yang mana pada dasarnya, teori himpunan Fuzzy merupakan perluasan dari teori himpunan klasik. Dimana dengan Fuzzy Logic, hasil yang keluar tidak akan selalu konstan dengan input yang ada. Cara kerja Fuzzy Logic secara garis besar terdiri dari input, proses dan output. Fuzzy Logic merupakan suatu teori himpunan logika yang dikembangkan untuk mengatasi konsep nilai yang terdapat diantara kebenaran (truth) dan kesalahan (false). Dengan menggunakan Fuzzy Logic nilai yang dihasilkan bukan hanya ya (1) atau tidak (0) tetapi seluruh kemungkinan diantara 0 dan 1. Ada beberapa hal yang perlu diketahui dalam memahami sistem Fuzzy antara lain (Agusman, Wijaya, \& Ingo, 2009) :

- Variabel Fuzzy merupakan variabel yang akan dibahas dalam suatu sistem Fuzzy.

- Himpunan Fuzzy merupakan suatu group yang mewakili suatu kondisi atau keadaan tertentu dalam suatu variabel Fuzzy.

- Semesta pembicaraan, merupakan keseluruhan nilai yang diperbolehkan untuk dioperasikan dalam suatu variabel Fuzzy.

- Domain adalah keseluruhan nilai yang diijinkan dalam semesta pembicaraan dan boleh dioperasikan dalam suatu himpunan Fuzzy.

\subsection{Metode Mamdani}

Dua metode defuzzyfikasi metode yang umum digunakan ialah :

a) Maksimum of Mean (MOM)

Metode ini didefinisikan sebagai berikut :

$$
v_{0}=\sum_{j=1}^{j} \frac{v_{j}}{J}
$$

Dimana :

$v_{0} \quad: \quad$ Nilai keluaran;

J : Jumlah harga maksimum;

$v_{j} \quad: \quad$ Nilai keluaran

maksimum ke-j

$\mu_{v}(v):$ Derajat keanggotaan elemen-elemen pada fuzzy set $v$

$v$ : Semesta pembicaraan

(b) Centre of Area (COA) 
Metode ini didefinisikan sebagai :

Dimana :

$$
v_{0}=\frac{\sum_{j=1}^{j} v_{k} \mu_{k}\left(v_{k}\right)}{\sum_{k=1}^{m} \mu_{v}\left(v_{k}\right)}
$$

$\begin{array}{ll}v_{0} & \text { Nilai keluaran; } \\ m & \text { Tingkat kuantisasi } \\ v_{k} & \text { Elemen ke- } k \\ \mu_{v}\left(v_{k}\right) & \text { Derajat keanggotaan } \\ & \text { elemen-elemen pada fuzzy } \\ & \text { set } v \\ v & \text { Semesta pembicaraan }\end{array}$

\subsection{Matlab}

Matlab (Matrix Laboratory) adalah sebuah Bahasa pemrograman tingkat tinggi berbasis matrix untuk komputasi teknik. Program ini merupakan produk komersial dari perusahaan Mathworks, Inc yang dikembangkan menggunakan Bahasa $\mathrm{C}++$ dan Assembler. Di dalam Matlab terdapat banyak terdapat banyak toolbox, yaitu kumpulan fungsi komprehensif yang digunakan untuk menyelesaikan kelas problem dan memungkinkan kita mempelajari dan mengaplikasikan teknologi tertentu. Berbagai toolbox dalam matlab antara lain signal processing, control system, neural network, fuzzy logic, wavelets, simulation, statistics, optimization, bioinformatics, genetic algorithm, dan lain-lain (Santosa, 2007).

Matlab banyak digunakan (Arhami \& Desiani, 2005) pada:

1. Matematika dan komputasi

2. Pengembangan dan algoritma

3. Pemrograman modeling, simulasi dan prototipe

4. Analisis dan statistic

5. Pengembangan aplikasi teknik.

Pada penelitian ini menggunakan bantuan matlab untuk simulasi grafik dan rule karena pada matlab menyediakan perkakas untuk membuat fuzzy inference System (FIS) yaitu Fuzzy Logic Toolbox yang didalamnya terdapat Graphical User Inferensi (GUI) untuk merancang FIS (Naba,2009), GUI tersebut adalah:

1. FIS Editor

2. Membership Function Editor

3. Rule Editor

4. Rule Viewer

\section{Surface Editor}

\subsection{Penelitian Terkait}

Penelitian yang terkait dalam penelitian ini sebagai berikut:

1. Penelitian Yang dilakukan oleh Ibrahim Rawabdeha, Abbas AlRefaie*b and Hamzeh Arabiyatd dengan Judul "Developing A Fuzzy Logic Decision Support System For Strategic Planning In Industrial Organizations. Penelitian ini bertujuan untuk menghasilkan dan mengevaluasi keluaran alternatif strategi yang merupakan langkah paling penting dalam tahap perumusan proses perencanaan strategis. Dalam model ini, tahap empat pencocokan matriks (SPACE, IE, BCG, dan Grand Strategy Matrix) telah digabungkan dengan hubungan untuk memilih strategi keluaran alternatif yang paling sering atau mengatur strategi antara matriks tersebut. Ada 134 hubungan atau kondisi yang dihasilkan dari kombinasi. Salah satu hubungan dapat terjadi ketika mengevaluasi delapan variabel dari empat matriks dari audit internal dan eksternal lingkungan organisasi. Hubungan antara empat matriks telah dimasukkan sebagai aturan dalam model ini menggunakan Logika Toolbox software Fuzzy yaitu MATLAB, dan sangat bergantung pada Alat antarmuka pengguna grafis (GUI). Model sederhana ini canggih dan tidak ada pengalaman sebelumnya dengan komputer atau pengetahuan tentang perencanaan strategis yang diperlukan untuk pengguna. dengan 8 input variabel yaitu Kami memiliki 8 input yaitu:

a) IFE: berkisar 1,0-4,0

b) EFE: berkisar 1,0-4,0

c) Relatif Market Share Posisi (RMSP): berkisar dari 0 ke 1

d) Industri Penjualan Pertumbuhan (ISGR): berkisar antara -20 sampai $+20$

e) $(\mathrm{IP}+\mathrm{CP})$ : Ini adalah resultan dari dua variabel: Posisi Industri (IP) \& posisi kompetitif (CP) di X - sumbu Matrix SPACE, (IP) berkisar 0-6, dan $(\mathrm{CP})$ berkisar antara -6 sampai 
0, Jadi, $(\mathrm{IP}+\mathrm{CP})$ berkisar antara -6 sampai +6

f) $(\mathrm{FP}+\mathrm{SP})$ : Ini adalah resultan dari dua variabel: Posisi Keuangan (FP) \& Stabilitas Posisi (SP) di Y sumbu Matrix SPACE, (FP) berkisar 0-6, dan (SP ) berkisar antara -6 sampai 0, Jadi, (FP + SP) yang berkisar antara -6 sampai +6 . Gambar 4 menunjukkan bagaimana $(\mathrm{FP}+\mathrm{SP})$ berkisar variabel dari -6 sampai +6 pada Y - sumbu dan bagaimana variabel $(\mathrm{IP}+\mathrm{CP})$ berkisar antara

g) sampai +6 pada sumbu $X$

h) Pertumbuhan Pasar: masukan dari variabel ini adalah apakah melebihi atau kurang dari 0,05

i) Posisi Kompetitif: berkisar 1,0-4,0

Hasil dari penelitian ini memuaskan.

2. Penelitian yang dilakukan oleh Sherly Jayanti, Sri Hartati dengan judul "Sistem Pendukung Keputusan Seleksi Anggota Paduan Suara Dewasa Menggunakan Metode Fuzzy Mamdani (Sanggar Bina Vokalia Menteng Palangka Raya). Penelitian ini bertujuan membantu pengambilan keputusan bagi pihak pengambil keputusan dalam menilai dan memilih anggota paduan suara kategori dewasa menggunakan logika fuzzy mamdani untuk mendapatkan keluaran berupa keputusan diterima atau tidak menjadi anggota paduan suara kategori dewasa. untuk variabel kriteria didapatkan dari hasil wawancara dengan Pembina Sanggar Bina Vokalia Menteng Palangka Raya, variabel kriteria yang digunakan pada penelitian ini adalah seperti kualitas yang sifatnya umum (seperti: usia, pegalaman dan kedisiplinan) dan kualitas teknik vokal (seperti: intonasi, artikulasi dan wilayah suara). dibentuk aturan yang bersesuaian dengan mengambil datadata berdasarkan pengalaman keputusan dari pembuat keputusan. Misal: Jika Usia peserta adalah konsisten dan Pengalaman peserta adalah pengalaman dan Kedisiplinan peserta adalah sangat disiplin maka keputusan dari kondisi tersebut adalah baik. Kondisi tiap kriteria yang berbeda-beda tadi kemudian dikombinasikan sehingga mengahasilkan keputusan yang berbeda pula. Pembentukan aturan dihasilkan dari kombinasi tiap kondisi tersebut yang dikenal dengan aturan (rule) keputusan.

3. Penelitian yang dilakukan oleh Aighner Ahsarif Ario, Novita Mardiani dengan judul "Sistem Informasi Simulasi Pemilihan Mata Kuliah Peminatan Mahasiswa Studi Kasus Program Studi Sistem Informasi STMIK GI MDP. Penelitian ini bertujuan sebagai alternative simulator bagi mahasiswa untuk mengenali kemampuan dan potensi sehingga dapat memutuskan pemilihan mata kuliah peminatan yang sesuai kedalam aplikasi simulasi yang berbasis logika fuzzy. Aplikasi simulasi ini dikembangkan dengan metodologi RUP (Rational Unified Process) dan menggunakan bahasa pemrograman Microsoft Visual Basic 2008 dan SQL Server 2008. Penentuan pemilihan mata kuliah peminatan dalam aplikasi simulasi ini dilakukan melalui proses simulasi memasukkan nilai mata kuliah. Aplikasi akan menampilkan informasi pilihan mata kuliah peminatan yang sesuai dengan kemampuan pengguna. Hasil analisis dan evaluasi menunjukkan bahwa aplikasi simulasi ini mudah digunakan. Diharapkan aplikasi simulasi ini dapat memberikan informasi dan solusi secara dini untuk menentukan pilihan mata kuliah peminatan.

4. Penelitian yang dilakukan oleh Pepi Dwi Ariani, Entin Martiana Kusuma, Dwi Kurnia Basuki dengan judul "Sistem Pendukung Keputusan Pemilihan Jurusan SMK Menggunakan Neuro-Fuzzy". Penelitian ini bertujuan mengimplementasikan metode NeuroFuzzy untuk menentukan SMK yang cocok berdasarkan kemampuan yang dimiliki siswa Sistem membutuhkan beberapa masukan berupa nilai, kemampuan dan minat siswa. Hasil dari sistem berupa nilai rekomendasi yang sesuai dengan nilai, kemampuan dan minat yang dimiliki. Kebutuhan 
input sistem berupa data nilai siswa yang menyangkut kompetensi di pelajaran atau kemampuan tertentu.

5. Penelitian yang dilakukan oleh Murdani dengan Judul: Sistem Pendukung Keputusan Pemilihan Pekerjaan Bagi Alumni Teknik Informatika Dengan Metode Simple Additive Weighting (Saw). Penelitian ini bertujuan Untuk menyelesaikan kriteria-kriteria pada setiap alternatif untuk Teknik Informatika. Mengetahui proses pembobotan untuk setiap kriteria-kriteria . ada empat alternatif yang ditentukan dalam pemilihan pekerjaan yaitu System analyst, Database administrator, System Enginering dan Application Developer. menggunakan metode Simple Additive Weighting (SAW) Meneruskan hasil analisa pembobotan dengan metode Simple Additive Weighting dengan menggunakan Software MATLAB. Hasil dari penelitian ini dapat membantu dalam proses pengambilan keputusan pemilihan pekerjaan bagi alumni Teknik Informatika dan dapat mengetahui kriteria-kriteria setiap alumni teknik informatika,Nilai yang di olah berupa angka atau numerik.

\section{METODE PENELITIAN}

\subsection{Jenis Penelitian}

Jenis Penelitian yang akan dilakukan pada penelitian kali ini termasuk dalam kategori penelitian Explanatory yaitu penelitian yang berisi pembuktian yang dibangun melalui teori dengan pendekatan pengolahan dengan metode fuzzy Mamdani. Serta menggunakan perangkat lunak Matlab sebagai alat bantu untuk mempermudah pengolahan datanya, dan PHP sebagai software pembangun aplikasinya.

\subsection{Populasi, Sampel dan Metode Pemilihan Sampel \\ 3.2.1 Populasi}

Populasi pada penelitian ini diambil dari Mahasiswa AMIK BSI Tasikmalaya yang sedang dalam aktif kuliah.

\subsubsection{Sampel}

Responden atau sampel diambil dari Mahasiswa semester 5 AMIK BSI Tasikmalaya. Dari data tersebut diambil sebanyak 80 responden untuk mengisi kuesioner yang berhubungan dengan Pemilihan Pekerjaan bagi mahasiswa AMIK BSI Tasikmalaya.

\subsubsection{Metode Pemilihan Sampel}

Mengingat jenis sampel yang diambil tidak dipilih secara acak dan unsur populasi yang terpilih menjadi sampel disebabkan karena sudah direncanakan oleh peniliti, teknik pengambilan sampel menggunakan teknik Purposive Sampling. Sampel diambil dengan maksud dan tujuan tertentu, seseorang diambil sebagai sampel karena peneliti menganggap bahwa seseorang tersebut memiliki informasi yang diperlukan bagi penelitian. Sesuai dengan teknik pendugaan model Maximum Likelihood.

\subsection{Metode Pengumpulan Data}

Data dikumpulkan dengan menggunakan metode survey. Penelitian ini merupakan penelitian yang dilakukan dengan menggunakan data kuantitatif dengan memberikan pertanyaan-pertanyaan yang dibuat oleh penulis untuk mengetahui bagaimana Pengaruh responden antara kemampuan, Jenis pekerjaan. Gaji, yang menentukan hasil dari pemilihan pekerjaan tersebut.

\subsection{Instrumen Penelitian}

Penelitian ini menggunakan instrument kuesioner yang dibuat dengan menggunakan pertanyaan tertutup. Dapat dengan mudah menjawab kuesioner dan data dari kuesioner tersebut dapat dengan cepat dianalisis secara statistik, serta pernyataan yang sama dapat diulang dengan mudah. Kuesioner pada penelitian ini dibuat dengan menggunakan skala interval atau Semantic Differential

\section{a. Teknik Analisis Data}

Logika fuzzy merupakan pengembangan dari logika primitif yang hanya mengenal keadaan, yaitu "ya" atau "tidak". Dengan adanya logika fuzzy, dapat mengenal peubah-peubah linguistik seperti "agak 
besar", "besar", "sangat besar", dan sebagainya. Dengan demikian, aplikasi logika fuzzi akan menyebabkan sistem lebih adaftif.

Dalam penelitian ini diasumsikan bahwa faktor penentu untuk mendapatkan keluaran berupa Rekomendasi pekerjaan yang paling tepat sesuai dengan variablevariable yang diinputkan, antara lain:

1. Umur

2. IPK

3. Gaji

Faktor-faktor tersebut kemudian menjadi varibel input, sehingga penerapan Fuzzification pada varibel tersebut yaitu dengan membuat ukuran secara linguistic pada variable tersebut, yaitu:

1. Umur mempunyai nilai linguistik: Muda, Sedang, Tua

2. IPK mempunyai nilai linguistik: Kurang Memuaskan, Memuaskan, Sangat Memuaskan.

3. Gaji mempunyai nilai linguistik: Rendah, Sedang, Tinggi.

\section{PEMBAHASAN}

Pada penelitian ini, digunakan logika fuzzy mamdani untuk mendapatkan keluaran berupa keputusan pekerjaan yang dipilih tersebut sesuai atau tidak dan menghasilkan rekomendasi berupa pekerjaan yang paling tepat dari sistem. Sistem pendukung keputusan ini digunakan untuk Mahasiswa AMIK BSI Tasikmalaya dengan menggunakan 3 variabel input yaitu IPK, Gaji dan Umur.

\section{A. Variabel Umur}

Variable umur yang digunakan dalam penelitian ini mengacu pada umur rata-rata mahasiswa dan alumni mahasiswa di AMIK BSI Tasikmalaya, Berikut Tabel Umur yang digunakan dalam penelitian ini.
Tabel 1 Nilai linguistik Umur (dalam bulan)

\begin{tabular}{lcc}
\hline $\begin{array}{c}\text { Nilai } \\
\text { Linguistik }\end{array}$ & Interval & Himpunan Fuzzy \\
\hline Muda & $17,20,23$ & {$[023]$} \\
Sedang & $20,23,26$ & {$[2026]$} \\
Tua & $23,26,29$ & {$[>26]$} \\
\hline
\end{tabular}

Ekspresi untuk fungsi keanggotaam fuzzy :

$$
\begin{aligned}
& \mu_{\text {muda }}(x) \\
& =\left\{\begin{array}{cc}
\frac{23-x}{3} & 20<x<23
\end{array}\right\} \\
& \mu_{\text {Sedang }(x)} \\
& =\left\{\begin{array}{ll}
\frac{(x-20)}{3} & 20<x \leq 23 \\
\frac{(26-x)}{3} & 23<x<26
\end{array}\right\}
\end{aligned}
$$

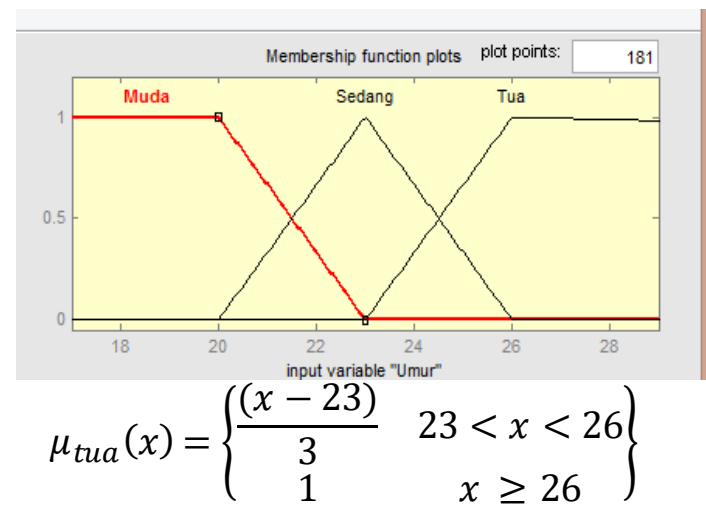

Gambar 1 Grafik Himpunan Umur

\section{B. IPK}

Nilai IPK tentu sangat berpengaruh juga dalam persyaratan pekerjaan yang diinginkan, karna IPK merupakan salah satu syarat administrasi yang harus dipenuhi. Nilai IPK yang diambil berdasarkan data BSI untuk range nilai atau nilai linguistiknya. Nilai IPK terdiri dari tiga nilai linguistik yaitu (kurang memuaskan, Memuaskan, dan Sangat Memuaskan) sebagai berikut:

Tabel 2 Nilai Linguistik IPK (Skala 4.0)

\begin{tabular}{lcc}
\hline \multicolumn{1}{c}{$\begin{array}{c}\text { Nilai } \\
\text { Linguistik }\end{array}$} & Interval & $\begin{array}{c}\text { Himpunan } \\
\text { Fuzzy }\end{array}$ \\
\hline $\begin{array}{l}\text { Sangat } \\
\text { Memuaskan }\end{array}$ & $2.40,2.70,3.00$ & {$[02.70]$} \\
Memuaskan & 2.70 .3 .00 .3 .30 & {$[2.703 .30]$} \\
$\begin{array}{l}\text { Kurang } \\
\text { Memuaskan }\end{array}$ & $\geq 3.60$ & {$[3.60 \infty]$} \\
\hline
\end{tabular}

Gambar 2 Variabel Linguistik IPK 


\section{Gaji}

Gaji merupakan salah satu hal yang mendorong atau memotivasi pegawai untuk bekerja atau mengabdi secara menyeluruh terhadap perusahaan dan suatu bentuk pembayaran periodik perusahaan kepada karyawannya yang dinyatakan dalam suatu kontrak kerja. Gaji yang dijadikan ukuran dalam penelitian ini mengikuti perkembangan terbaru informasi gaji di dareah Tasikmalaya. Nilai gaji mempunyai 3 nilai linguistik yaitu ,Rendah, Sedang dan Tinggi

Tabel 3 Nilai Linguistik Gaji (00000)

\begin{tabular}{lcc}
\hline $\begin{array}{c}\text { Nilai } \\
\text { Linguistik }\end{array}$ & $\begin{array}{c}\text { Interval } \\
\text { (NA) }\end{array}$ & $\begin{array}{c}\text { Himpunan } \\
\text { Fuzzy }\end{array}$ \\
\hline Rendah & $15,19,23$ & {$[1523]$} \\
Sedang & $19,23,27$ & {$[1927]$} \\
Tinggi & $>27$ & {$[27 \infty]$} \\
\hline
\end{tabular}

Gambar 3 Grafik Himpunan Gaji

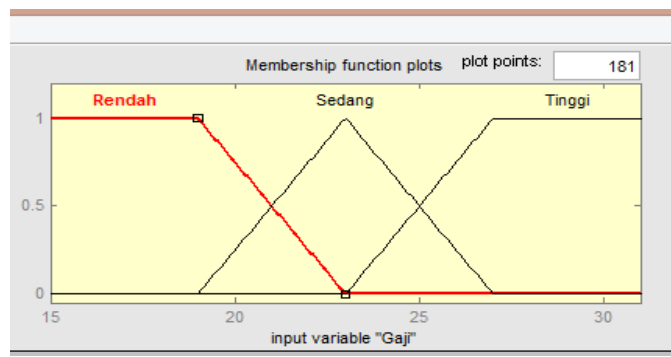

D. Keputusan

Tabel 4 Nilai linguistik Keputusan

\begin{tabular}{|c|c|c|}
\hline Nilai Linguistik & $\begin{array}{c}\text { Interval } \\
(\%)\end{array}$ & $\begin{array}{l}\text { Himpunan } \\
\text { Fuzzy }\end{array}$ \\
\hline Indus tri/Pabrik & $\leq 15$ & {$\left[\begin{array}{ll}0 & 15\end{array}\right]$} \\
\hline Bank & $\leq 18$ & {$\left[\begin{array}{ll}16 & 18\end{array}\right]$} \\
\hline $\begin{array}{l}\text { Pegawai } \\
\text { Pemerintah }\end{array}$ & $\leq 20$ & [19 20] \\
\hline Pendidik & $>20$ & {$[21 \infty]$} \\
\hline
\end{tabular}

Gambar 4 Grafik himpunan Keputusan

\section{E. Proses Inferensi}

Dengan menggunakan Fuzzy Logic maka didapatkan hasil keputusan sebagai berikut

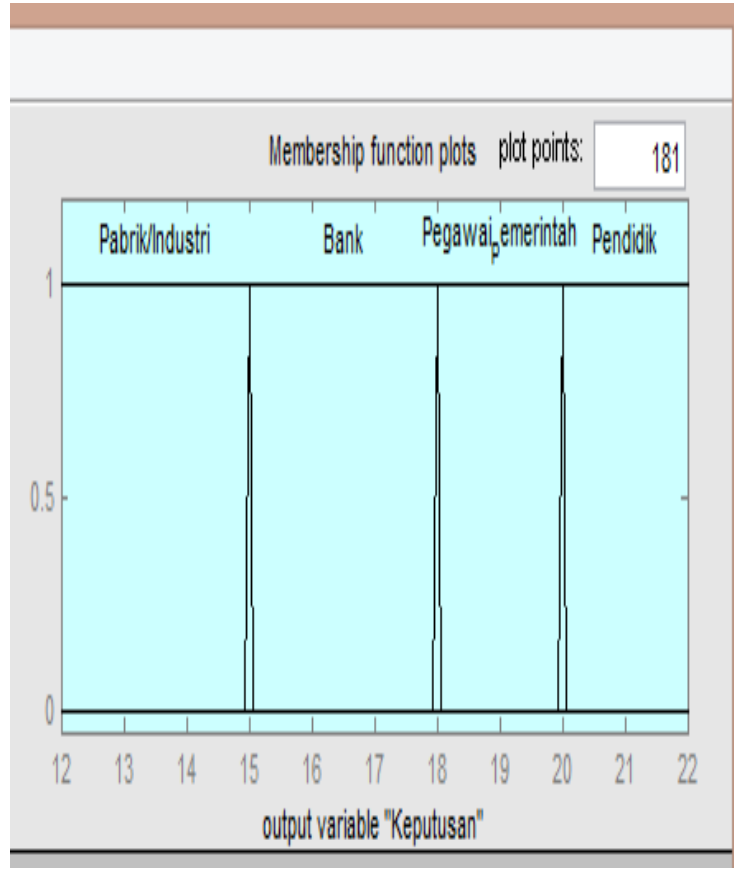

1. Jika Usia Muda dan IPK Kurang Memuaskan dan Gaji Rendah maka Keputusannya adalah Pabrik/Industri

2. Jika Usia Muda dan IPK Kurang Memuaskan dan Gaji Sedang maka Keputusannya adalah Pabrik/Industri

3. Jika Usia Muda dan IPK Kurang Memuaskan dan Gaji Tinggi maka Keputusannya adalah Pabrik/Industri

4. Jika Usia Muda dan IPK Memuaskan dan Gaji Rendah maka Keputusannya adalahh Pabrik/Industri

5. Jika Usia Muda dan IPK Memuaskan dan Gaji Sedang maka Keputusannya adalah Bank

6. Jika Usia Muda dan IPK Memuaskan dan Gaji Tinggi maka Keputusannya adalah Bank

7. Jika Usia Muda dan IPK Sangat Memuaskan dan Gaji Rendah maka Keputusannya adalah Bank

8. Jika Usia Muda dan IPK Sangat Memuaskan dan Gaji Sedang maka Keputusannya adalah Bank

9. Jika Usia Muda dan IPK Sangat Memuaskan dan Gaji Tinggi maka Keputusannya adalah Bank

10.Jika Usia Sedang dan IPK Kurang Memuaskan dan Gaji Rendah maka Keputusannya adalah Pabrik/Industri

11.Jika Usia Sedang dan IPK Kurang Memuaskan dan Gaji Sedang maka Keputusannya adalah Pabrik/Industri 
12.Jika Usia Sedang dan IPK Kurang Memuaskan dan Gaji Tinggi maka Keputusannya adalah Pabrik/Industri

13.Jika Usia Sedang dan IPK Memuaskan dan Gaji Rendah maka Keputusannya adalah Pabrik/Industri

14.Jika Usia Sedang dan IPK Memuaskan dan Gaji Sedang maka Keputusannya adalah Bank

15.Jika Usia Sedang dan IPK Memuaskan dan Gaji Tinggi maka Keputusannya adalah Pegawai Pemerintah

16.Jika Usia Sedang dan IPK Sangat Memuaskan dan Gaji Rendah maka Keputusannya adalah Bank

17.Jika Usia Sedang dan IPK Sangat Memuaskan dan Sedang maka Keputusannya adalah Pendidik

18. Jika Usia Sedang dan IPK Sangat Memuaskan dan Tinggi maka Keputusannya adalah Pegawai Pemerintah

19.Jika Usia Tua dan IPK Kurang Memuaskan dan Gaji Rendah maka Keputusannya adalah Pabrik/Industri

20.Jika Usia Tua dan IPK Kurang Memuaskan dan Gaji Sedang maka Keputusannya adalah Pabrik/Industri

21.Jika Usia Tua dan IPK Kurang Memuaskan dan Gaji Tinggi maka Keputusannya adalah Pabrik/Industri

22.Jika Usia Tua dan IPK Memuaskan dan Gaji Rendah maka Keputusannya adalah Pabrik/Industri

23.Jika Usia Tua dan IPK Memuaskan dan Gaji Sedang maka Keputusannya adalah Pendidik

24.Jika Usia Tua dan IPK Memuaskan dan Gaji Tinggi maka Keputusannya adalah Pendidik

25.Jika Usia Tua dan IPK Sangat Memuaskan dan Gaji Rendah Keputusannya adalah Bank

26. Jika Usia Tua dan IPK Sangat Memuaskan dan Sedang Keputusannya adalah Pegawai Pemerintah

27.Jika Usia Tua dan IPK Sangat Memuaskan dan Tinggi maka Keputusannya adalah Pendidik

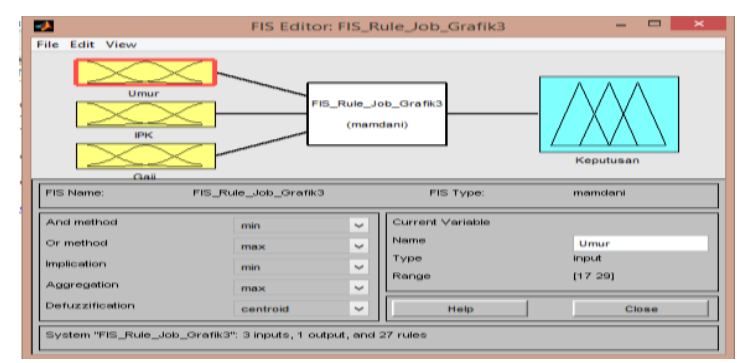

Gambar 5 Pembentukan Rule Pada Matlab

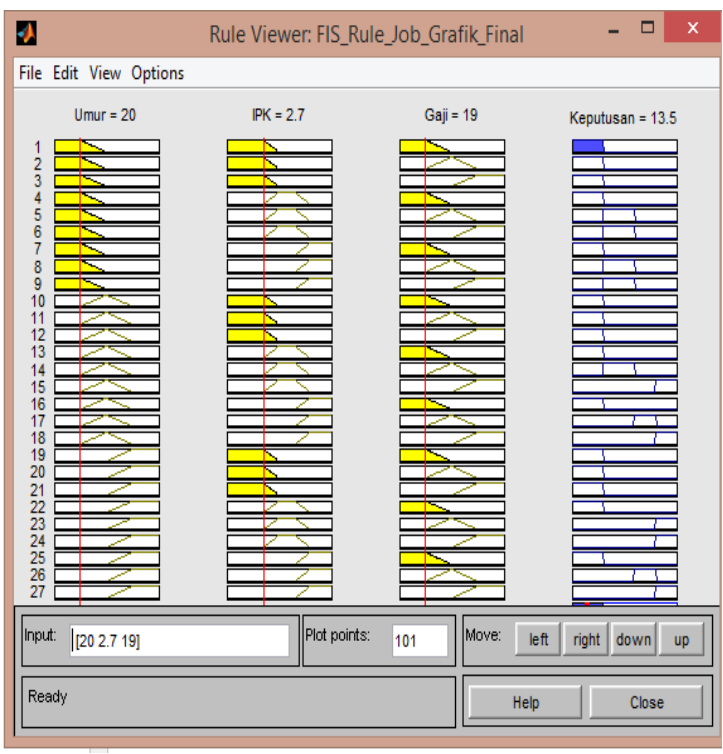

Gambar 6 Rule Pada Matlab

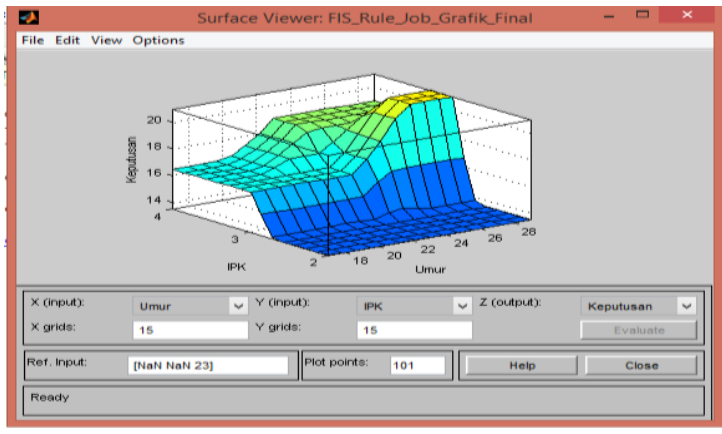

Gambar 7 Survace pada Matlab

Karena sistem terdiri dari beberapa aturan, maka Inferensi diperoleh dari kumpulan dan korelasi antar aturan. Dalam hal ini, akan digunakan metode Max (Maximum). Solusi himpunan fuzzy diperoleh dengan cara mengambil nilai maksimum aturan, 
kemudian menggunakannya untuk memodifikasi daerah fuzzy, dan mengaplikasikannya ke output.

Surface ini berguna untuk melihat gambar pemetaan antara varibael-variabel input dan variabel-variabel output.

\section{F. Proses Defuzzyfikasi}

Dalam menghitung derajat keanggotaan, dapat dianalogikan dengan kasus data yang pertama dari kuesioner. Yaitu mahasiswa memilih pekerjaan Bank dengan umur 19 tahun dan dengan IPK 2.70 dan Gaji yang di Inginkan 19 (00000) sebagai berikut : maka dapat diuraikan sebagai berikut :

1. Umur

$$
\mu_{\text {muda }}(x)=\left\{\begin{array}{cc}
1 & x \leq 20 \\
\frac{23-x}{3} & 20<x<23
\end{array}\right\}
$$

Bernilai 1 , masuk ke Nilai Linguistik "Muda"

2. IPK

$$
\begin{aligned}
& \mu_{\text {kurang memuaskan }}(y) \\
& =\left\{\begin{array}{cc}
1 & x \leq 2.70 \\
\frac{3.00-x}{0.3} & 2.70<x<3.00
\end{array}\right\}
\end{aligned}
$$

Bernilai 1 karena $\leq 2,70$ masuk ke Nilai linguistik "Kurang Memuaskan"

3. Gaji

$$
\begin{aligned}
& \mu_{\text {Rendah }}(x) \\
& =\left\{\begin{array}{cc}
1 & x \leq 19 \\
\frac{23-19}{4} & 19<x<23
\end{array}\right.
\end{aligned}
$$

Hasilnya $=1$ ( Termasuk ke Nilai

Linguis tik "Rendah")

Sehingga Menjadi Muda - Kurang

Memuas kan - Rendah

$y$

$$
=\frac{(20 * 1.00)+(2.70 * 1.00)+(19 * 1.00)}{(1.00+1.00+1.00)}
$$

$$
y=\frac{20+2.7+19}{3}
$$

Maka Nilai yang didapatkan adalah 13,9, dari hasil perhitungan sistem pekerjaan Bank tidak tepat, rekomendasinya adalah Pabrik/Industri.

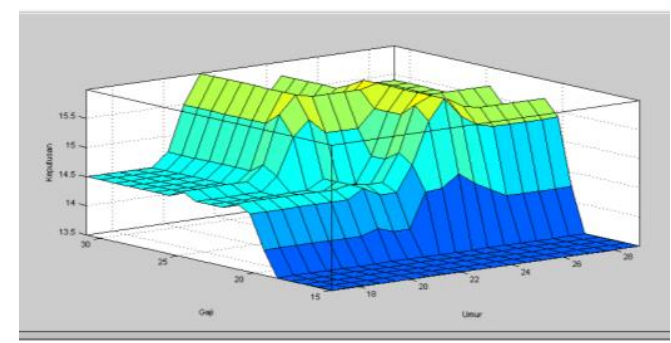

Gambar 8 Grafik yang terbentuk dari Rule yang dibuat pada Matlab pada kasus 1

\section{G. Hasil Pengolahan Data}

Hasil pengukuran pada penelitian ini menggunakan metode Postest yaitu mengolah data hasil questioner menggunakan Sistem Pendukung Keputusan untukPemilihan Pekerjaan. Selengkapnya dapat dilihat pada tabel berikut :

Tabel 5 Hasil Pengolahan Sistem dan Rekomendasi sistem

\begin{tabular}{|c|c|c|c|c|c|c|}
\hline 5 & $\begin{array}{l}\text { Mira } \\
\text { wati }\end{array}$ & $\begin{array}{l}\text { Pend } \\
\text { idik }\end{array}$ & $\begin{array}{l}\mathrm{Mu} \\
\mathrm{da}\end{array}$ & $\begin{array}{c}\mathrm{S} \\
\mathrm{M}\end{array}$ & $\begin{array}{l}\text { Ting } \\
\text { gi }\end{array}$ & Bank \\
\hline 6 & $\begin{array}{l}\text { Soni } \\
\text { Gum } \\
\text { ilar }\end{array}$ & PP & $\begin{array}{l}\mathrm{Mu} \\
\mathrm{da}\end{array}$ & $\begin{array}{c}\mathrm{S} \\
\mathrm{M}\end{array}$ & $\begin{array}{l}\text { Ting } \\
\text { gi }\end{array}$ & Bank \\
\hline 7 & $\begin{array}{l}\text { M } \\
\text { Jafar }\end{array}$ & PP & $\begin{array}{l}\mathrm{Mu} \\
\mathrm{da}\end{array}$ & $\begin{array}{l}\mathrm{S} \\
\mathrm{M}\end{array}$ & $\begin{array}{l}\text { Ting } \\
\text { gi }\end{array}$ & Bank \\
\hline 8 & $\begin{array}{l}\text { Haer } \\
\text { ul } \\
\text { Fata } \\
\text { h }\end{array}$ & PP & $\begin{array}{l}\mathrm{Mu} \\
\mathrm{da}\end{array}$ & $\begin{array}{c}\mathrm{S} \\
\mathrm{M}\end{array}$ & $\begin{array}{l}\text { Ting } \\
\text { gi }\end{array}$ & Bank \\
\hline 9 & Gian & Ban & Tua & M & Ting & Pendi \\
\hline
\end{tabular}

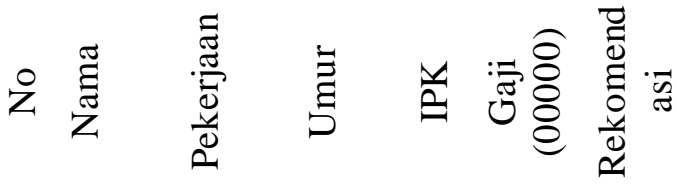

\begin{tabular}{lllllll}
\hline 1 & $\begin{array}{l}\text { Wild } \\
\text { an }\end{array}$ & PP & Sed & S & Ting & PP \\
& Yasa & & ang & gi & \\
2 & Sri & Pend & Mu & S & Ting & Bank
\end{tabular}
Raha idik da M gi yu

$\begin{array}{lllllll}3 & \text { Arif } & \text { PP } & \text { Sed } & \text { M } & \text { Ting } & \text { PP } \\ \text { A } & & \text { ang } & & \text { gi } & \\ & \text { Ajiz } & & & & & \\ \text { 4 } & \text { Nuru } & \text { PP } & \text { Sed } & \text { S } & \text { Ting } & \text { PP } \\ & 1 & & \text { ang } & \text { M } & \text { gi } & \\ & \text { Ihsa } & & & & & \end{array}$
Ihsa $\mathrm{n}$ 


\begin{tabular}{|c|c|c|c|c|c|c|c|}
\hline & tara & $\mathrm{k}$ & & & gi & dik & \\
\hline & & & & & & & Pabrik \\
\hline 1 & Ellis & Ban & Sed & M & Ting & PP & $\mathrm{M}$ ang \\
\hline 0 & $\mathrm{P}$ & $\mathrm{k}$ & ang & & gi & & \\
\hline 1 & Rah & Ban & $\mathrm{Mu}$ & S & Ting & Bank & K Ting \\
\hline 1 & $\begin{array}{l}\mathrm{mi} \\
\mathrm{F}\end{array}$ & $\mathrm{k}$ & da & M & gi & & $\begin{array}{l}\text { /Indus } \\
\text { tri }\end{array}$ \\
\hline 1 & & PP & $\mathrm{Mu}$ & $\mathrm{S}$ & Ting & Bank & $\begin{array}{llllll}\text { Yuni } & \begin{array}{l}\text { Pend } \\
\text { idik }\end{array} & \begin{array}{l}\text { Mu } \\
\text { da }\end{array} & \text { M } & \text { Ting } & \text { Bank }\end{array}$ \\
\hline & $\begin{array}{l}\text { Setia } \\
\text { di }\end{array}$ & & & & & & Dari hasil pengujian Sistem Pendukung \\
\hline $\begin{array}{l}1 \\
3\end{array}$ & $\begin{array}{l}\text { Hen } \\
\text { dri } \\
\text { M }\end{array}$ & $\mathrm{PP}$ & $\begin{array}{l}\mathrm{Mu} \\
\mathrm{da}\end{array}$ & $\begin{array}{l}\mathrm{S} \\
\mathrm{M}\end{array}$ & $\begin{array}{l}\text { Ting } \\
\text { gi }\end{array}$ & Bank & $\begin{array}{l}\text { Keputusan Pemilihan Pekerjaan dapat } \\
\text { diambil kesimpulan bahwa sistem dapat } \\
\text { menangani proses pemilihan pekerjaan }\end{array}$ \\
\hline $\begin{array}{l}1 \\
4\end{array}$ & $\begin{array}{l}\text { Rah } \\
\text { ma } \\
\text { Ispar } \\
\text { ani }\end{array}$ & PP & $\begin{array}{l}\mathrm{Mu} \\
\mathrm{da}\end{array}$ & $\begin{array}{l}\mathrm{S} \\
\mathrm{M}\end{array}$ & $\begin{array}{l}\text { Ting } \\
\text { gi }\end{array}$ & Bank & $\begin{array}{l}\text { berdasarkan data yang diinputkan dan } \\
\text { rekomendasi yang tepat. Sistem } \\
\text { Pendukung Keputusan ini menghasilkan } \\
\text { rekomendasi pekerjaan yang sesuai dengan }\end{array}$ \\
\hline $\begin{array}{l}1 \\
5\end{array}$ & $\begin{array}{l}\text { Elis } \\
\text { Istiq } \\
\text { oma }\end{array}$ & $\begin{array}{l}\text { Pend } \\
\text { idik }\end{array}$ & $\begin{array}{l}\mathrm{Mu} \\
\mathrm{da}\end{array}$ & $\begin{array}{l}\mathrm{S} \\
\mathrm{M}\end{array}$ & $\begin{array}{l}\text { Ting } \\
\text { gi }\end{array}$ & Bank & $\begin{array}{l}\text { data yang dimiliki mahasiswa. Hasil ini } \\
\text { lebih baik dibandingkan dengan hanya } \\
\text { menebak nebak pekerjaan apa yang tepat }\end{array}$ \\
\hline 1 & Fitri & $\mathrm{PP}$ & M & $S$ & Ting & Bank & dan perkiraan bisa diterima atau tidak pada \\
\hline 6 & $\begin{array}{l}\text { a } \\
\text { Nur }\end{array}$ & & da & $\mathrm{M}$ & gi & & sebuah perusahaan tersebut. \\
\hline $\begin{array}{l}1 \\
7\end{array}$ & $\begin{array}{l}\text { Jayyi } \\
\mathrm{n}\end{array}$ & $\begin{array}{l}\text { Ban } \\
\mathrm{k}\end{array}$ & $\begin{array}{l}\text { Mi } \\
\text { da }\end{array}$ & $\begin{array}{l}\mathrm{S} \\
\mathrm{M}\end{array}$ & $\begin{array}{l}\text { Ting } \\
\text { gi }\end{array}$ & Bank & V. PENUTUP \\
\hline & & & & & & & Kesimpulan \\
\hline 1 & Fuji & Ban & $\mathrm{M}$ & $\mathrm{S}$ & Ting & Bank & Dari penelitian yang telah dilakukan \\
\hline 8 & $\begin{array}{l}\text { Fauji } \\
\text { ah }\end{array}$ & $\mathrm{k}$ & da & M & gi & & $\begin{array}{l}\text { hingga implementasi Logika Fuzzy pada } \\
\text { sistem pendukung keputusan pemilihan }\end{array}$ \\
\hline 1 & Yogi & $\begin{array}{l}\text { Pend } \\
\text { idik }\end{array}$ & $\begin{array}{l}\mathrm{Mu} \\
\mathrm{da}\end{array}$ & $\begin{array}{l}\mathrm{S} \\
\mathrm{M}\end{array}$ & $\begin{array}{l}\text { Ting } \\
\text { gi }\end{array}$ & Bank & $\begin{array}{l}\text { pekerjaan, dapat diambil beberapa } \\
\text { kesimpulan berikut: }\end{array}$ \\
\hline 2 & Iis & PP & $\mathrm{Mu}$ & $\mathrm{S}$ & Ting & Bank & pendukung \\
\hline $\mathbf{0}$ & $\begin{array}{l}\text { Solih } \\
\text { at }\end{array}$ & & da & $\mathrm{M}$ & gi & & $\begin{array}{l}\text { pemilihan pekerjaan menggunakan } 3 \\
\text { variabel yaitu variabel umur,ipk dan }\end{array}$ \\
\hline 2 & Jajan & Pend & $\mathrm{M}$ & $\mathrm{S}$ & Ting & Bank & gaji dan metode yang digunakan \\
\hline 1 & $\begin{array}{l}\mathrm{g} \\
\text { Jaya }\end{array}$ & idik & da & M & gi & & $\begin{array}{l}\text { adalah Fuzzy Logic, yang } \\
\text { menghasilkan output dari }\end{array}$ \\
\hline $\begin{array}{l}2 \\
2\end{array}$ & Ida & $\begin{array}{l}\text { Ban } \\
\mathrm{k}\end{array}$ & $\begin{array}{l}\mathrm{Mu} \\
\mathrm{da}\end{array}$ & $\begin{array}{l}\mathrm{K} \\
\mathrm{M}\end{array}$ & $\begin{array}{l}\text { Ting } \\
\text { gi }\end{array}$ & $\begin{array}{l}\text { Pabrik } \\
\text { /Indus } \\
\text { tri }\end{array}$ & $\begin{array}{l}\text { berupa pekerjaan yang sesuai atau } \\
\text { tidak dan rekomendasi dari sistem } \\
\text { berupa pekerjaan yang tepat. }\end{array}$ \\
\hline 2 & $\begin{array}{l}\text { Ahm } \\
\text { da Y }\end{array}$ & PP & $\begin{array}{l}\text { Sed } \\
\text { ang }\end{array}$ & $\begin{array}{l}\mathrm{K} \\
\mathrm{M}\end{array}$ & $\begin{array}{l}\text { Sed } \\
\text { ang }\end{array}$ & $\begin{array}{l}\text { Pabrik } \\
\text { /Indus } \\
\text { tri }\end{array}$ & $\begin{array}{l}\text { 2. Sistem pendukung keputusan } \\
\text { pemilihan pekerjaan dapat membantu } \\
\text { mahasiswa yang ingin memilih }\end{array}$ \\
\hline 2 & $\begin{array}{l}\text { Nikk } \\
\text { a }\end{array}$ & $\begin{array}{l}\text { Pabr } \\
\text { ik }\end{array}$ & $\begin{array}{l}\text { Sed } \\
\text { ang }\end{array}$ & $\mathrm{M}$ & $\begin{array}{l}\text { Ting } \\
\text { gi }\end{array}$ & PP & $\begin{array}{l}\text { pekerjaan yang tepat sesuai dengan } \\
\text { kemampuannya, sehingga bisa } \\
\text { mempersiapkan diri untuk pekerjaan }\end{array}$ \\
\hline $\begin{array}{l}2 \\
5\end{array}$ & Ari & $\begin{array}{l}\text { Ban } \\
\mathrm{k}\end{array}$ & $\begin{array}{l}\text { Sed } \\
\text { ang }\end{array}$ & M & $\begin{array}{l}\text { Ting } \\
\text { gi }\end{array}$ & PP & $\begin{array}{l}\text { yang diinginkan atau yang disarankan } \\
\text { oleh sistem. }\end{array}$ \\
\hline 2 & Tauf & Ban & Sed & $\mathrm{K}$ & Sed & Pabrik & pendukung \\
\hline 6 & $\mathrm{ik} \mathrm{H}$ & $\mathrm{k}$ & an & $\mathrm{M}$ & an & $\begin{array}{l}\text { /Indus } \\
\text { tri }\end{array}$ & $\begin{array}{l}\text { pemilihan pekerjaan dibuat secara } \\
\text { khusus untuk mahasiswa BSI tingkat }\end{array}$ \\
\hline $\begin{array}{l}2 \\
7\end{array}$ & $\begin{array}{l}\text { Fah } \\
\text { mi }\end{array}$ & $\begin{array}{l}\text { Pabr } \\
\text { ik }\end{array}$ & $\begin{array}{l}\mathrm{Mu} \\
\mathrm{da}\end{array}$ & M & $\begin{array}{l}\text { Sed } \\
\text { ang }\end{array}$ & Bank & akhir yang akan mengakhiri masa \\
\hline
\end{tabular}


perkuliahnnya, karena untuk jenis pekerjaanya dibatasi.

\section{Saran}

Berdasarkan pada hasil pembahasan, penelitian dan implementasi yang telah dilakukan, ada beberapa saran yang dapat penulis berikan yaitu:

1. Diperlukan domain dan hosting khusus untuk menyimpan Fuzzy Decission Support System (FDSS) Pemilihan Pekerjaan ini sehingga dapat diakses secara Intranet dilingkungan AMIK BSI Tasikmalaya atau bahkan bisa dikembangkan dan dibuat secara online sehingga bisa digunakan oleh user lain.

2. Diperlukan lebih banyak data untuk dapat menguji kehandalan sistem, salah satu caranya adalah dengan menguji sistem dengan input data yang sangat banyak untuk mengetahui kelemahan sistemnya

3. Penggunaan atau penambahan algoritma maupun metode yang lain juga dapat digunakan untuk menambah kehandalan sistem pada masa mendatang.

4. Sistem ini juga bisa dikembangkan kembali dan diterapkan untuk semua user yang membutuhkan sistem ini.

5. Penelitian diatas lebih difokuskan kepada metode yang digunakan, dan aplikasinya masih sangat sederhana karena aplikasi yang dibangun hanya menekankan pada proses dan hasil. Sedangkan kenyamanan dan user friendy pada aplikasi ini untuk sementara belum maksimal. Apabila dipergunakan untuk proses sesungguhnya maka sangat dianjurkan untuk memperbaiki interface pada aplikasinya agar lebih nyaman digunakan.

\section{DAFTAR PUSTAKA}

[1] Agusman, L., Wijaya, S., \& Ingo, Y. (2009). Aplikasi Logika Fuzzy Untuk Analisis Tes Kepribadian. Jakarta: Binus University.
[2] Aighner Ahsarif Ario, Novita Mardiani.Sistem Informasi Simulasi Pemilihan Mata Kuliah Peminatan Mahasiswa Studi Kasus Program Studi Sistem Informasi STMIK GI MDP.

[3] Arhami, M., \& Desiana, A. (2005). Permrograman Matlab. Yogyakarta: Andi.

[4] Dwi Ariani, Pepi.,Entin Martiana Kusuma, dan Dwi Kurnia Basuki.(2010).Sistem Pendukung Keputusan Pemilihan Jurusan SMK Menggunakan Neuro-Fuzzy.

[5] Hasan, Iqbal. (2002). Pokok-Pokok Materi Statistik II: Statistik Inferensial. Jakarta: Bumi Aksara.

[6] Jayanti, Sherly., Sri Hartati.(2012).Sistem Pendukung Keputusan Seleksi Anggota Paduan Suara Dewasa Menggunakan Metode Fuzzy Mamdani (Sanggar Bina Vokalia Menteng Palangka Raya. IJCCS, Vol.6, No.1, January 2012, pp. 55 66 ISSN: 1978-1520

[7] Jogianto. 2003. Sistem Teknologi Informasi. Yogyakarta: Andi.

[8] Murdani.Sistem Pendukung Keputusan Pemilihan Pekerjaan Bagi Alumni Teknik Informatika Dengan Metode Simple Additive Weighting (Saw). STMIK Budi Darma Medan. Volume : IV, Nomor: 2, Agustus 2013 ISSN : 2301-9425

[10] Rawabdeh, Ibrahim., Abbas Al-Refaie dan Hamzeh Arabiyat.(2013).Developing A Fuzzy Logic Decision Support System For Strategic Planning In Industrial Organizations. International Journal of Intelligent Systems and Applications in Engineering.ISSN:2147-67992

[11] Santosa, B. (2007). Data Mining Terapan dengan MATLAB. Yogyakarta: Graha Ilmu. 
[12] Sukardi, Dewa Ketut. (1987). Bimbingan Karier di Sekolah-sekolah. Jakarta: Ghalia Indonesia.

[13] Turban, Efraim dan Jaye Aronson. (2000). Decision Support Systems and Intelligent Systems (Sistem Pendukung Keputusan dan System Cerdas). Jilid 1. Yogyakarta: Andi. 